\title{
Effect of Heat Treatment on Microstructure and Mechanical Properties of $\mathrm{Mg}_{94} \mathrm{Zn}_{2} \mathrm{Y}_{4}$ Alloy
}

\author{
Xu Min, Teng Xinying, Yang Chaoping, Zhang Jinyang \\ University of Jinan, Jinan 250022, China
}

\begin{abstract}
The effect of heat treatment at $773 \mathrm{~K}$ for $48 \mathrm{~h}$ on microstructure and mechanical properties of as-cast $\mathrm{Mg}_{94} \mathrm{Zn}_{2} \mathrm{Y}_{4}$ (at $\%$ ) alloy was investigated. The results show that block shaped and laths structured 18R long period stacking ordered (LPSO) phase forms directly from the melt. After heat treatment, vast majority of the block shaped and laths structured LPSO phase changes into fine lamellar or needle-like shaped 14H. During heat treatment, a great fraction of LPSO phase is transformed from 18R structure to $14 \mathrm{H}$ type. $18 \mathrm{R}$ and $14 \mathrm{H}$ can co-exist within the $\alpha-\mathrm{Mg}$ matrix after solution treatment. As a result, grain sizes are refined to 14 24 $\mu \mathrm{m}$ (the average grain size is about $19 \mu \mathrm{m}$ ). The co-existence of the block shaped and laths structured phase and needle-like shaped phase help to improve the ultimate tensile strength, yield strength and elongation from $182 \mathrm{MPa}, 135 \mathrm{MPa}$ and $10.2 \%$ in as-cast alloy to $245 \mathrm{MPa}, 157 \mathrm{MPa}$ and $13.8 \%$, respectively.
\end{abstract}

Key words: Mg-Zn-Y alloy; yttrium; phase transformation; long period stacking ordered structures; mechanical properties

In the last decades, ternary $\mathrm{Mg}-\mathrm{Zn}-\mathrm{Y}$ alloys have attracted considerable attention due to their excellent mechanical properties and unique microstructures ${ }^{[1-7]}$. The remarkable microstructures of $\mathrm{Mg}-\mathrm{Zn}-\mathrm{Y}$ alloys usually contain icosahedral quasicrystal ${ }^{[1,2]}$ and long-period stacking ordered (LPSO) structures, including $6 \mathrm{H}, 10 \mathrm{H}, 14 \mathrm{H}, 18 \mathrm{R}$ and $24 \mathrm{R}$ types $^{[3]}$. By contrast, the LPSO structures can be obtained more easily and can indeed strengthen magnesium alloys much more effectively. Y. Kawamura et al. ${ }^{[6]}$ developed the $\mathrm{Mg}_{97} \mathrm{Zn}_{1} \mathrm{Y}_{2}$ (at\%) alloy by rapidly solidified powder metallurgy processing which exhibited extremely high yield strength of $610 \mathrm{MPa}$ with an elongation of 5\% at ambient temperature. As for the LPSO structures, the $18 \mathrm{R}$ and $14 \mathrm{H}$ structures are the major components ${ }^{[8-12]}$. The crystal structures of $18 \mathrm{R}$ and $14 \mathrm{H}$ remain controversial. It was suggested in recent works $^{[10,13]}$ that $18 \mathrm{R}$ has an ordered base-centred monoclinic structure $(a=1.112 \mathrm{~nm}, b=1.926 \mathrm{~nm}$, $c=4.689 \mathrm{~nm}, \beta=83.25^{\circ}$ ). The $18 \mathrm{R}$ was initially regarded as identical to the $\mathrm{X}-\mathrm{Mg}_{12} \mathrm{YZn}$ phase that was identified by Z. P. Luo and S. Q. Zhang ${ }^{[1,4]}$. Recent studies by Y. M. Zhu et al. ${ }^{[13]}$ have shown that the $18 \mathrm{R}$ phase has not only an ordered arrangement of its closely packed planes but also an ordered distribution of $\mathrm{Y}$ and $\mathrm{Zn}$ atoms within some of the closely packed planes. The composition of $18 \mathrm{R}$ is in fact $\mathrm{Mg}_{10} \mathrm{YZn}$ instead of $\mathrm{Mg}_{12} \mathrm{YZn}$. Initially, it was reported that the $14 \mathrm{H}$ had a hexagonal lattice $(a=0.321 \mathrm{~nm} \text { and } c=3.694 \mathrm{~nm})^{[1,4]}$. However, a more recent study ${ }^{[10,13]}$ indicated that the unit cell of $14 \mathrm{H}$ was, in fact, hexagonal with lattice parameters of $a=1.11 \mathrm{~nm}$ and $c=3.65 \mathrm{~nm}$. The composition of $14 \mathrm{H}$ is $\mathrm{Mg}_{12} \mathrm{YZn}$, identical to that of the X-phase, i.e. $14 \mathrm{H}$ is the $\mathrm{X}$-phase. The composition of $14 \mathrm{H}$ with $\mathrm{Mg}_{12} \mathrm{YZn}$ (at\%) is commonly accepted. The 18R unit cell has three ABCA-type (bold letters represent the building blocks in the stacking sequence of the $18 \mathrm{R}$ and $14 \mathrm{H}$ structures) building blocks arranged in the same shear direction, while the $14 \mathrm{H}$ unit cell has two ABCA-type building blocks arranged in opposite shear directions ${ }^{[10]}$.

However, it is not clear whether the $14 \mathrm{H}$ structure can form directly from the melt during conventional casting, on whether $18 \mathrm{R}$ and $14 \mathrm{H}$ can co-exist at some particular temperatures. Although some possible stacking sequences and unit cells have been proposed for $18 \mathrm{R}$ and $14 \mathrm{H}$ structures ${ }^{[12,14]}$, the

Received date: November 10, 2015

Foundation item: National Natural Science Foundation of China (51571102)

Corresponding author: Teng Xinying, Ph. D., School of Materials Science and Engineering, University of Jinan, Jinan 250022, P. R. China, Tel: 0086-531-82765317, E-mail: mse_tengxy@ujn.edu.cn

Copyright (C) 2016, Northwest Institute for Nonferrous Metal Research. Published by Elsevier BV. All rights reserved. 
effect of these phases on mechanical properties is rarely reported. Moreover, heat treatment is effective techniques for improving the mechanical properties of $\mathrm{Mg}$ alloys containing the LPSO phase. The unambiguous answers to such questions are important as they can provide a rational design of alloy microstructures for particular applications. Therefore effects of heat treatment on the microstructure and mechanical properties of $\mathrm{Mg}_{94} \mathrm{Zn}_{2} \mathrm{Y}_{4}$ were investigated in the current study.

\section{Experiment}

Mg-Zn-Y alloy of nominal composition $\mathrm{Mg}_{94} \mathrm{Zn}_{2} \mathrm{Y}_{4}$ (at\%) was prepared with pure $\mathrm{Mg}(99.9 \mathrm{wt} \%)$, pure $\mathrm{Zn}(99.9 \mathrm{wt} \%)$ and Mg-28.41wt\% Y master alloy. The alloy was melted in an electric resistance furnace under the protection of a mixed gas atmosphere of $\mathrm{CO}_{2}$ and $\mathrm{SF}_{6}$ with the ratio of $100: 1 . \mathrm{Mg}$ was first added to the crucible at $600{ }^{\circ} \mathrm{C}$, and $\mathrm{Zn}$ was added to the molten $\mathrm{Mg}$ at $700{ }^{\circ} \mathrm{C}$. Subsequently $\mathrm{Mg}-28.41 \mathrm{wt} \% \mathrm{Y}$ master alloy was added. After all the materials were melted at $750{ }^{\circ} \mathrm{C}$ and the temperature was held for $30 \mathrm{~min}$, the melt was stirred at regular intervals to make it homogeneous enough and to eliminate undissolved $\mathrm{Y}$. The melt was then cast into a preheated iron mold. The samples were covered with $\mathrm{MgO}$ powder, solution treated at $773 \mathrm{~K}$ for $48 \mathrm{~h}$, followed by water quenching. The grain size was measured by the standard linear intercept method using an Olympus stereomicroscope. The volume fraction of the secondary phase in the alloy was determined by Image-Pro Plus 6.0 and 10 images were used to calculate the average volume fractions. Tensile strength tests were performed five times by a universal tester at a constant displacement rate of $2 \mathrm{~mm} / \mathrm{min}$ at room temperature. Brinell hardness was measured ten times by a sclerometer for each sample. The tensile strength, elongation and brinell hardness were evaluated by averaging the measured values.

With carefully prepared samples, the phases were determined by X-ray diffraction (XRD, D8-ADVANCE, Germany) with $\mathrm{Cu} \mathrm{K \alpha}$ radiation. The as-cast sample was investigated by differential scanning calorimetry (DSC, STA409EP, Germany) at a heating rate of $10{ }^{\circ} \mathrm{C} / \mathrm{min}$. In order to avoid the damage to the equipment from the vaporization of $\mathrm{Mg}$, the samples were put into a specially designed tantalum crucible with a cover. Microstructure was examined by scanning electron microscopy (SEM, QUANTA FEG250, America) equipped with an energy disperse X-ray spectrometer (EDS). SEM was equipped with energy dispersive X-ray spectrometry (EDXS, X-MAX50, Britain) for analyzing the compositions of some intermetallic phases. SEM observations were mechanically polished and then etched with $4 \mathrm{~mL}$ nitric acid and $96 \mathrm{~mL}$ ethanol.

\section{Results and Discussion}

\subsection{Microstructure of the as-cast $\mathrm{Mg}_{94} \mathrm{Zn}_{\mathbf{2}} \mathrm{Y}_{\mathbf{4}}$ alloy}

The XRD pattern of the as-cast $\mathrm{Mg}_{94} \mathrm{Zn}_{2} \mathrm{Y}_{4}$ alloy in Fig.1a reveals that there are both $\alpha-\mathrm{Mg}$ and $\mathrm{Mg}_{10} \mathrm{Y}_{1} \mathrm{Zn}_{1}$ phase in the as-cast alloy. Fig.1b shows the SEM image of the as-cast $\mathrm{Mg}_{94} \mathrm{Zn}_{2} \mathrm{Y}_{4}$ alloy. A secondary phase appears in the form of a three-dimensional continuous network in the matrix. In some regions of the secondary phase, block shaped and laths structures can be observed. In the works that have been reported by now, the 18R-LPSO phases usually form with various shapes, like particles, blocks, plates, and laths. The secondary phase is determined to be $18 \mathrm{R}$. The quantitative EDS measurements indicate that the average chemical composition is in the range of $\mathrm{Mg}-8.4 \mathrm{at} \% \mathrm{Y}-7.8 \mathrm{at} \% \mathrm{Zn}$, i.e., $\mathrm{Mg}_{10} \mathrm{Y}_{1} \mathrm{Zn}_{1}$. It indicates that the $18 \mathrm{R}$ structure can form directly from the alloy melt. Moreover, the $18 \mathrm{R}$ shows block shaped and laths structures.

Fig. 2 displays the DSC curves for the as-cast $\mathrm{Mg}_{94} \mathrm{Zn}_{2} \mathrm{Y}_{4}$ alloy. The result shows that the melt point temperatures of the secondary phase (18R) and the alloy are established to be about 805 and $856 \mathrm{~K}$, respectively, consuming approximately the same amount of heat. As far as we know, the endothermic peaks in the heating progress stand for melting of phases. Based on the result above, it is then reasonable to choose temperature $723 \mathrm{~K}$ during heat treatment. Instead, the exothermic peaks of DSC curve in the cooling progress stand up for the formation of $\alpha-\mathrm{Mg}$ dendrites and the secondary phase (18R). In conclusion, the binary eutectic reaction processes of as-cast $\mathrm{Mg}_{94} \mathrm{Zn}_{2} \mathrm{Y}_{4}$ alloy is, $\mathrm{L} \rightarrow \alpha-\mathrm{Mg}+$ $\mathrm{Mg}_{10} \mathrm{Y}_{1} \mathrm{Zn}_{1}$. According to the $\mathrm{X}$-ray diffraction pattern, EDS and DSC analyses, the matrix phase and the secondary phase could be identified as the $\alpha-\mathrm{Mg}$ and the $\mathrm{Mg}_{10} \mathrm{Y}_{1} \mathrm{Zn}_{1}$ phase, respectively. The volume fraction of the second phases is estimated about $18 \%$ with the thickness of about $5 \sim 15 \mu \mathrm{m}$.
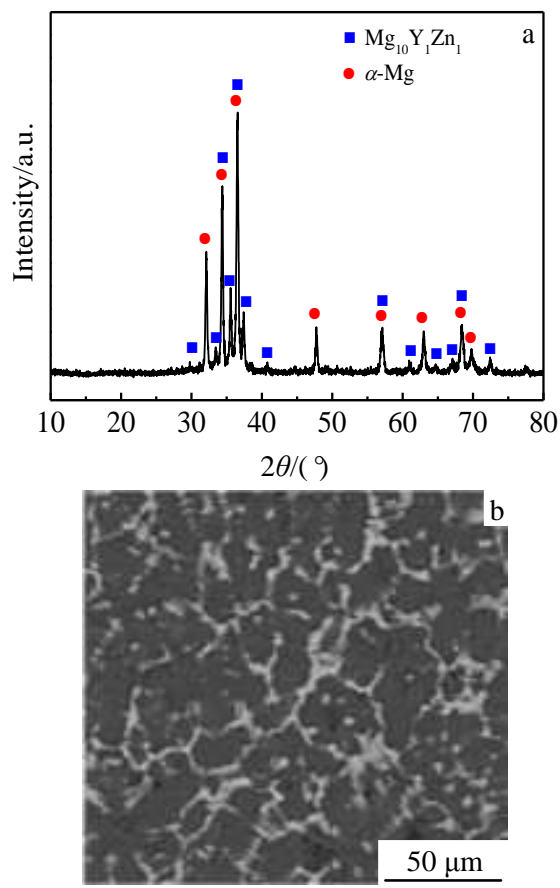

Fig.1 XRD pattern (a) and SEM back-scattered electron image (b) of the as-cast $\mathrm{Mg}_{94} \mathrm{Zn}_{2} \mathrm{Y}_{4}$ ternary alloy 


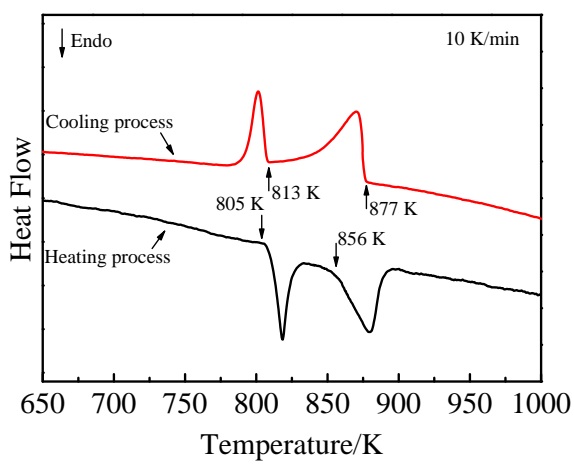

Fig.2 DSC curves of the as-cast $\mathrm{Mg}_{94} \mathrm{Zn}_{2} \mathrm{Y}_{4}$ alloy

With respect to the average chemical composition of the secondary phase, the composition of the laths regions is the same with other regions of the secondary phase.

\subsection{Heat treated $\mathrm{Mg}_{94} \mathrm{Zn}_{2} \mathrm{Y}_{4}$ alloy}

2.2.1 Microstructure of the heat treated $\mathrm{Mg}_{94} \mathrm{Zn}_{2} \mathrm{Y}_{4}$ alloy

Fig.3a shows the SEM microstructure of the heat treated $\mathrm{Mg}_{94} \mathrm{Zn}_{2} \mathrm{Y}_{4}$ alloy after solution treatment at $773 \mathrm{~K}$ for $48 \mathrm{~h}$. It can be noted that the laths shaped LPSO phases change into needle-like phases (with the thickness of about 3 9 $\mu \mathrm{m}$ ) with the increase of the volume fraction of the secondary phase (which is estimated about 43\%). Compared with the SEM image (back-scattered electron) of the as-cast $\mathrm{Mg}_{94} \mathrm{Zn}_{2} \mathrm{Y}_{4}$ ternary alloy, Fig.1b, significant differences in microstructures between the two samples are observed, suggesting the $18 \mathrm{R}$ LPSO is not thermal stable during heat treated process, which is in accordance with the EDS and XRD analysis results that $14 \mathrm{H}$ phases are found in heat treated $\mathrm{Mg}_{94} \mathrm{Zn}_{2} \mathrm{Y}_{4}$ alloy.

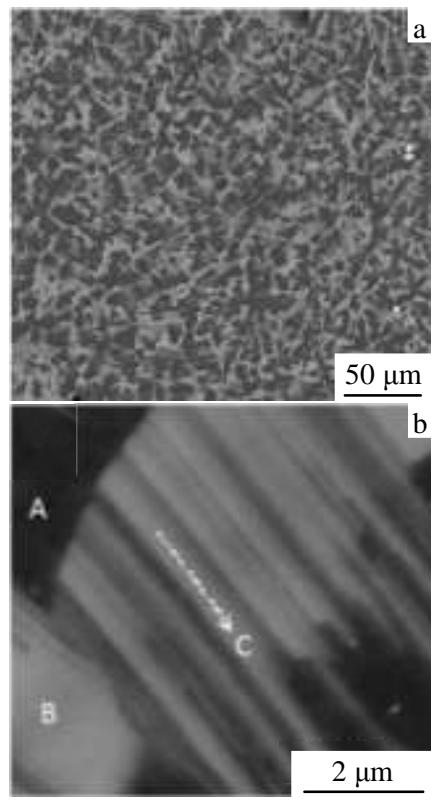

Fig.3 SEM image (back-scattered electron) of the heat treated $\mathrm{Mg}_{94}-$ $\mathrm{Zn}_{2} \mathrm{Y}_{4}$ alloy (a); enlarged image for a clearer observation (b)
Chemical analysis by EDS was conducted on heat treated specimens and the results show that the compositions of the $\alpha-\mathrm{Mg}$ matrix (area A in Fig.3b), block compound (area B in Fig.3b) and acicular phases (C marked by an arrow in Fig.3b) are approximately $\mathrm{Mg}-2.5 \mathrm{at} \% \mathrm{Y}-0.5 \mathrm{at} \% \mathrm{Zn}, \quad \mathrm{Mg}-8.4 \mathrm{at} \% \mathrm{Y}-$ 7.8at\% $\mathrm{Zn}$ and $\mathrm{Mg}-5.1$ at\% Y-4.3at\%Zn, respectively.

As shown in Fig.4, the corresponding $\mathrm{X}$-ray diffraction pattern reveals that the $\alpha-\mathrm{Mg}, \mathrm{Mg}_{10} \mathrm{Y}_{1} \mathrm{Zn}_{1}$ and $\mathrm{Mg}_{12} \mathrm{Y}_{1} \mathrm{Zn}_{1}$ phases (i.e., $\mathrm{X}$-phase), are detected for the heat treated $\mathrm{Mg}_{94} \mathrm{Zn}_{2} \mathrm{Y}_{4}$ alloy. No other phase is detected within the sensitivity limit of XRD. The diffraction peaks of the X-phase are indexed based on the PDF card no.36-1273 and the work of Luo $^{[4]}$. According to the EDS and XRD results, it could be identified that the matrix is $\alpha-\mathrm{Mg}$ and the second phase is $\mathrm{Mg}_{10} \mathrm{Y}_{1} \mathrm{Zn}_{1}$ and $\mathrm{Mg}_{12} \mathrm{Y}_{1} \mathrm{Zn}_{1}$ phase.

The $\mathrm{Mg}_{10} \mathrm{Y}_{1} \mathrm{Zn}_{1}$ phase, which is enriched with both $\mathrm{Y}$ and $\mathrm{Zn}$ elements, was first reported by $\mathrm{Luo}^{[4]}$ as a type of long period stacking ordered (LPSO) structure with 18-fold layers in each period. However, for the present structural model of $18 \mathrm{R}$, the stoichiometric composition is $\mathrm{Mg}_{10} \mathrm{Y}_{1} \mathrm{Zn}_{1}$, which is distinguishably different from the one (i.e., $\operatorname{Mg}_{12} \mathrm{Y}_{1} \mathrm{Zn}_{1}$ ) commonly accepted in the literature. The measurements in the present work indicate that the actual composition of $18 \mathrm{R}$ is closer to $\mathrm{Mg}_{10} \mathrm{Y}_{1} \mathrm{Zn}_{1}$ than to $\mathrm{Mg}_{12} \mathrm{Y}_{1} \mathrm{Zn}_{1}$. Furthermore, this $14 \mathrm{H}$ structure has an atomic composition of $\mathrm{Mg}_{12} \mathrm{Y}_{1} \mathrm{Zn}_{1}$, which is identical to that of the equilibrium $X-M_{12} Y_{1} Z_{1}$ phase in the $\mathrm{Mg}-\mathrm{Y}-\mathrm{Zn}$ system $^{[15]}$. It is worth mentioning that the composition of $18 \mathrm{R}$ has long and often been assumed to be $\mathrm{Mg}_{12} \mathrm{Y}_{1} \mathrm{Zn}_{1}$ merely because the $18 \mathrm{R}$ structure was mistakenly taken as the structure of the equilibrium $\mathrm{X}-\mathrm{Mg}_{12} \mathrm{Y}_{1} \mathrm{Zn}_{1}$ phase in the $\mathrm{Mg}-\mathrm{Y}-\mathrm{Zn}$ system in the original paper by Luo and Zhang ${ }^{[4]}$. In addition, as for 14H-LPSO, only fine lamellar shape or single lamella (needle-like shape in this paper) is observed ${ }^{[6-13]}$. Therefore, it can be inferred that the $18 \mathrm{R}$ structure is found to transform gradually to the $14 \mathrm{H}$ structure and they can co-exist, which is a trend supported by previous studies ${ }^{[8,9,11,12]}$. Moreover, it should be noted that coexistence of the $18 \mathrm{R}$ and $14 \mathrm{H}$ structures in the heat-treated samples, compared with the dominant $18 \mathrm{R}$ structure in the as-cast samples, supports the fact that $18 \mathrm{R}$ is partially transformed into $14 \mathrm{H}$.

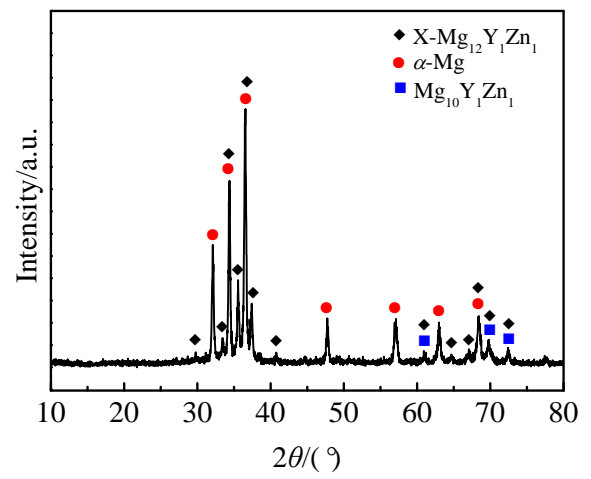

Fig.4 XRD pattern of the heat treated $\mathrm{Mg}_{94} \mathrm{Zn}_{2} \mathrm{Y}_{4}$ ternary alloy 
2.2.2 Phase transformation from $18 \mathrm{R}$ to $14 \mathrm{H}$ of the heat treated $\mathrm{Mg}_{94} \mathrm{Zn}_{2} \mathrm{Y}_{4}$ alloy

It has been reported that the $18 \mathrm{R}-\mathrm{LPSO}$ phases can change into $14 \mathrm{H}$ type for $\mathrm{Mg}$-Y-Zn system when being heat-treated at above $673 \mathrm{~K}^{[14,16,17]}$. The present results have shown that additions of a very small amount of $\mathrm{Zn}$ and $\mathrm{Y}$ to $\mathrm{Mg}$ lead to formation of a long-period chemical-ordered as well as stacking-ordered structure (see Fig.3).

Abe et al. ${ }^{[7]}$ have reported that the construction of LPSO phases involves two processes, introducing stacking faults (SFs) in the $\alpha$-Mg matrix and supplying the solute elements (Y and $\mathrm{Zn}$ ) to the faulted layers. Suzuki et al. reported that the $\mathrm{Zn}$ addition to the Mg-Y binary alloys leads to the formation of $\mathrm{SF}$ in the alloys ${ }^{[18]}$. The stacking sequence of the common intrinsic stacking faults was $\mathrm{ABABCACA}^{[19]}$, with the ABCA-type stacking sequence. From the stacking sequence point of view, 18R LPSO structure is constructed from several stacking faults, which can be easily formed around the interdendritic spacing and grain boundary and the lamellar LPSO may nucleate through stacking faults. In addition, faulted $18 \mathrm{R}$ regions containing four $\alpha-\mathrm{Mg}$ atomic layers provide a simple transitional path to $14 \mathrm{H}$. During solution treatment at $773 \mathrm{~K}$, the diffusion mobilities of $\mathrm{Y}$ and $\mathrm{Zn}$ atoms are accelerated and it is relatively easier for solute atoms to diffuse into the SFs since the faulted layers could be considered as high-diffusivity paths ${ }^{[20]}$. The diffusions of $\mathrm{Y}$ and $\mathrm{Zn}$ atoms into stacking faults will reach chemical ordering in order to form $14 \mathrm{H}$ structure. Once a $14 \mathrm{H}$ unit cell is nucleated, it could grow as time goes on ${ }^{[21]}$. Consequently, the formation of $14 \mathrm{H}$ LPSO structure is a diffusion-controlled process in this $\mathrm{Mg}-\mathrm{Y}-\mathrm{Zn}$ alloy.

\subsection{Mechanical properties of the $\mathrm{Mg}_{94} \mathrm{Zn}_{2} \mathrm{Y}_{4}$ alloy}

A tensile test was performed on these cast alloys at room temperature with a strain-rate of $2 \mathrm{~mm} / \mathrm{min}$. The comparison of the tensile properties of $\mathrm{Mg}_{94} \mathrm{Zn}_{2} \mathrm{Y}_{4}$ alloy with different conditions is shown in Table 1 . The results indicate that the solution treatment drastically increases the ultimate tensile strength and elongation of the tested alloy. The ultimate tensile strength and elongation are raised to $245 \mathrm{MPa}$ and $13.8 \%$, respectively, increased by about $34.6 \%$ and $35.3 \%$ with respect to that of as-cast condition. However, the yield strength seems no sensitivity to the solution treatment, increasing slightly from $135 \mathrm{MPa}$ to $157 \mathrm{MPa}$. In addition, the hardness test shows that the increment of the hardness, relative to the counterpart of the as-cast alloy, approximates $27.7 \%$, from $65 \mathrm{BHW}$ to $83 \mathrm{BHW}$.

Table 1 Tensile properties of $\mathrm{Mg}_{94} \mathrm{Zn}_{2} \mathrm{Y}_{4}$ alloy at room temperature in different conditions

\begin{tabular}{cccc}
\hline & $\begin{array}{c}\text { Ultimate tensile } \\
\text { strength/MPa }\end{array}$ & $\begin{array}{c}\text { Yield strength/ } \\
\mathrm{MPa}\end{array}$ & $\begin{array}{c}\text { Elongation/ } \\
\%\end{array}$ \\
\hline As-cast & 182 & 135 & 10.2 \\
Solution treated & 245 & 157 & 13.8 \\
\hline
\end{tabular}

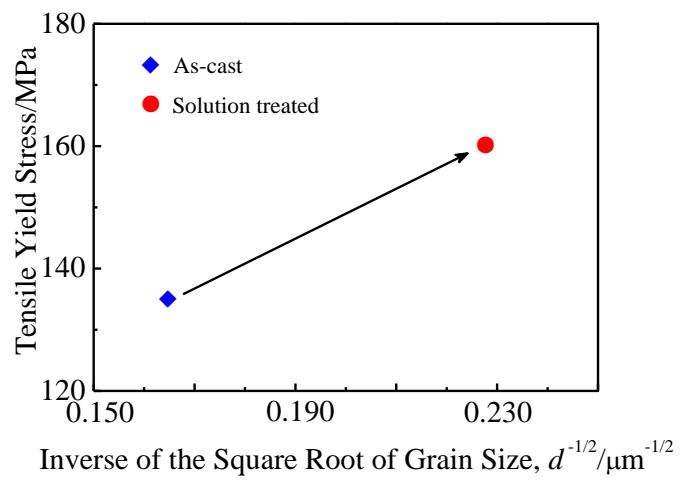

Fig.5 Plot of inverse of square root of grain size against the tensile yield strength of the $\mathrm{Mg}_{94} \mathrm{Zn}_{2} \mathrm{Y}_{4}$ alloy in different conditions

The results above indicate that the solution treatment at 723 $\mathrm{K}$ for $48 \mathrm{~h}$ is appropriate for and propitious to the studied alloy.

It is commonly believed that the solid solution strengthening of RE elements, the precipitates strengthening, the secondary phase strengthening of LPSO structures, together with grain-boundary strengthening, are all effective strengthening sources for Mg-RE-Zn alloys ${ }^{[14,16,22,23]}$.

The variations in the tensile yield stress TYS are plotted against the inverse of the square root of grain sized $d^{1 / 2}$ to determine the relationship between the grain size and yield strength of the studied alloy. This plot, known as the Hall-Petch plot, is shown in Fig.5. The $\sigma_{\mathrm{TYS}}$ of the heat treatment condition, as compared to that of the as-cast condition, can be explained by the grain size behavior. It has been also demonstrated that the strengthening effect of LPSO phase is dominant over that from the grain refinement, especially for alloys with higher LPSO volume fractions ${ }^{[24]}$. In addition, the decrease in the grain size also helps to the elongation increase ${ }^{[25,26]}$. It is worth noting that the uniform distribution of the second phase also plays a significant role in improvement of the elongation ${ }^{[27]}$. Comparing Fig.1b and Fig.3a, it can be seen that the distribution of second phase is more uniform when the studied alloy heat treated at $773 \mathrm{~K}$ for $48 \mathrm{~h}$. In the as-cast alloy, due to the low volume fraction of the second phase, the effect of the distribution of the second phase on the advancement of the elongation becomes slight. Also, hardness of the matrix elevates drastically due to the stress concentration promoted in the matrix around the LPSO phase, refined grains by heat treatment.

\section{Conclusions}

1) The $18 \mathrm{R}$ structure phase forms directly from the $\mathrm{Mg}_{94} \mathrm{Zn}_{2} \mathrm{Y}_{4}$ alloy melt, while the $14 \mathrm{H}$ phase forms in a solid-state transformation during heat treatment. 18R phase and $14 \mathrm{H}$ phase can co-exist within the $\alpha-\mathrm{Mg}$ matrix after heat treatment at $773 \mathrm{~K}$ for $48 \mathrm{~h}$. In addition, the actual composition of $18 \mathrm{R}$ is closer to $\mathrm{Mg}_{10} \mathrm{Y}_{1} \mathrm{Zn}_{1}$ than to $\mathrm{Mg}_{12} \mathrm{Y}_{1} \mathrm{Zn}_{1}$ 
and this $14 \mathrm{H}$ structure has an atomic composition of $\mathrm{Mg}_{12} \mathrm{Y}_{1} \mathrm{Zn}_{1}$ in the study alloy.

2) The studied alloy after solution treatment at $773 \mathrm{~K}$ for 48 $\mathrm{h}$ possesses the highest ultimate tensile strength (245 MPa), yield strength (157 MPa), $83 \mathrm{BHW}$ and excellent elongation $(13.8 \%)$, exhibiting outstanding comprehensive mechanical properties.

\section{References}

1 Luo Z, Zhang S, Tang Y et al. Journal of Alloys and Compounds[J], 1994, 209(1-2): 275

2 Geng J W, Teng X Y, Zhou G R et al. Journal of Alloys and Compounds[J], 2013, 577(22): 498

3 Polmear I J. Materials Transactions[J], 1996, 37(1): 12

4 Luo Z P, Zhang S Q. Journal of Materials Science Letters[J], 2000, 19(19): 813

5 Zhao Z W, Teng X Y, Zhou G R et al. Rare Metal Materials and Engineering[J], 2014, 43(4): 791 (in Chinese)

6 Kawamura Y, Hayashi K, Inoue A et al. Materials Transactions [J], 2001, 42(7): 1172

7 Abe E, Kawamura Y, Hayashi K et al. Acta Materials[J], 2002, 50(15): 3845

8 Itoi T, Seimiya T, Kawamura Y et al. Scripta Materialia[J], 2004, 51(2): 107

9 Matsuda M, Ii S, Kawamura Y et al. Materials Science \& Engineering A[J], 2005, 393(1): 269

10 Zhu Y M, Weyland M, Morton A J et al. Scripta Materialia[J], 2009, 60(11): 980

11 Ono A, Abe E, Itoi $\mathrm{T}$ et al. Materials Transactions[J], 2008, 49(5): 990

12 Lee J, Sato K, Konno T J et al. Materials Transactions[J], 2009, 50(1): 222
13 Zhu Y M, Morton A J, Nie J F et al. Acta Materials[J], 2010, 58(8): 2936

14 Yan B S, Dong X P, Ma R et al. Materials Science \& Engineering $A[\mathrm{~J}], 2014,594(594): 168$

15 Shao G, Varsani V, Fan Z. Comput Coupling of Phase Diagrams Thermochem [J], 2006, 30: 286

16 Yoshimoto S, Yamasaki M, Kawamura Y. Materials Transactions[J], 2006, 47(4): 959

17 Kawamura Y, Yamasaki M. Materials Transactions[J], 2007, 48(11): 2986

18 Suzuki M, Kimura T, Koike J K et al. Materials Science \& Engineering $A[\mathrm{~J}], 2004$, S387-389(36): 706

19 Hirth J P, Lothe J. Theory of Dislocations[M]. New York: John Wiley \& Sons, 1982: 354

20 Zhang J S, Chen C J, Que Z P et al. Materials Science \& Engineering $A[\mathrm{~J}], 2012$, 552: 81

21 Liu H, Xue F, Bai J et al. Materials Science \& Engineering A[J], 2013, 585(11): 261

22 Zhang J, Leng Z, Liu S et al. Journal of Alloys and Compounds[J], 2011, 509(29): 7717

23 Bi G, Fang D, Zhao L et al. Journal of Alloys and Compounds[J], 2011, 509(32): 8268

24 Tong L B, Li X H, Zhang H J. Materials Science \& Engineering $A[\mathrm{~J}], 2013,563(563): 177$

25 Paramsothy M, Gupta M. Journal of Alloys and Compounds[J], 2013, 580(4): 604

26 Yamasaki M, Hashimoto K, Hagihara K. Acta Materials[J], 2011, 59(9): 3646

27 Wang Q, Liu K, Wang Z et al. Journal of Alloys and Compounds[J], 2014, 602(602): 32

\title{
热处理对 $\mathrm{Mg}_{94} \mathrm{Zn}_{2} \mathrm{Y}_{4}$ 合金微观组织与力学性能的影响
}

\author{
许 敏, 滕新营, 杨超平, 张金洋 \\ (济南大学, 山东 济南 250022)
}

\begin{abstract}
摘 要: 研究了在 $773 \mathrm{~K} 、 48 \mathrm{~h}$ 条件下热处理对 $\mathrm{Mg}_{94} \mathrm{Zn}_{2} \mathrm{Y}_{4}$ 合金的微观组织与力学性能的影响。结果表明, 块形和板条结构的 $18 \mathrm{R}$ 长周期堆垛结构相可直接从熔体凝固过程中形成。热处理后, 绝大多数的块形和板条结构相转变为细片状或针状的 $14 \mathrm{H}$ 相。在热处理 过程中, 有相当体积分数的 LPSO (长周期堆垛结构) 相由 $18 \mathrm{R}$ 转变为 $14 \mathrm{H}$ 。结果表明, 经过热处理, 块形和板条结构相与针状相可以 在 $\alpha-\mathrm{Mg}$ 基体中共存, 并作为影响因素, 使合金晶粒得到细化, 晶粒尺寸为 14 24 $\mu \mathrm{m}$ (平均晶粒尺寸为 $19 \mu \mathrm{m}$ ), 使极限抗拉强度、屈 服强度以及伸长率分别由铸态时的 $182 \mathrm{MPa} 、 135 \mathrm{MPa}$ 和 $10.2 \%$ 提高至 $245 \mathrm{MPa} 、 157 \mathrm{MPa}$ 和 $13.8 \%$ 。
\end{abstract}

关键词: Mg-Zn-Y 合金; 钇; 相转变; 长周期堆垛结构; 力学性能

作者简介: 许 敏, 男, 1989 年生, 硕士生, 济南大学材料科学与工程学院, 山东 济南 250022, E-mail: 15288845105@163.com 